\title{
Põhja paikkondlik traditsioon komide rahvameditsiinis ${ }^{1}$
}

Irina Iljina

\begin{abstract}
Teesid: Välitööde materjalide põhjal valminud artiklis vaadeldakse rahvameditsiini eripärasid komide kõige põhjapoolsemas rühmas - ižmalaste (komi k iz'valaste) juures. Tundra hõivamise ja neenetsitelt laenatud põdrakasvatuse arenedes kujunes neil välja ere kultuurilis-olmeline spetsiifika, mis avaldus meditsiiniteadmiste struktuuris, ravivahendite sortimendis, toitumis- ja hügieenitavade süsteemis. Nimetatud rühma rahvameditsiini iseloomustab erakordne ratsionalism, mis väljendub selles, et maagilisi ravivõtteid kasutatakse harva, rahvatervendajate seas on ülekaalus luude paikapanijad, skeptilised ollakse neenetsi šamaanide suhtes.

Komidel arenenud esivanemate austamise raames on kultusobjektiks muutunud 20. sajandi esimesel poolel Ižma ääres tegutsenud luupaigaldaja Tandze Marja. Tuntud tervendaja mütologiseerimisele aitavad suuresti kaasa massiteabevahendid ja mõneti on see alguse saanud rahvusliku intelligentsi initsiatiivil.
\end{abstract}

Märksõnad: Euroopa põhjaosa põlisrahvad, komid, kultuuriline adaptsioon, rahvaarstid, rahvameditsiin.

Lahendades inimese põhjapiirkonna äärmuslike tingimustega adapteerumise probleeme on otstarbekas võtta appi põlisrahvaste kogemus ja traditsioonid. Ümbruse ja kliimaga kohanedes töötasid nad välja mooduse, kuidas kaitsta ennast ebasoodsate loodustingimuste eest, kasutades selleks aktiivselt elukeskkonna ressursse. Komide etnograafilise uurimise materjalidest nähtub, et üheks tähtsaimaks kultuurilise adaptatsiooni mehhanismiks on rahvameditsiin, mille eripärad on moodustunud kõigi looduslike ja majanduslike ning sotsiaalmajanduslike faktorite süsteemis (Iljina 1997; Volodin \& Iljina 2000). Klimaatilised ja geograafilised elamistingimused, majanduslik ja olmeline elukord, sotsiaalne korraldus ning etnokultuurilised kontaktid tingisid nii haiguste iseloomu kui ka nende ravimise ja ennetamise meetodid, luues ühtlasi rahvameditsiini rahvuslikku eripära. Eredaks näiteks sellest, kuidas mõjuvad 
need faktorid rahvuse meditsiinikultuurile, on ižmalaste rahvameditsiin, mida käsitleb käesolev artikkel. Selles kajastuvad 1984. ja 2006. aasta suve etnograafiliste välitööde materjalid Komi vabariigi Ižma rajoonis (Ižma, Mohtša, Sizjabsk, Gam, Kipijevo).

Ižmalased on komide kõige põhjapoolsem etnograafiline rühm, mis moodustus 17. ja 18. sajandil Petšoora keskosa ja selle lisajõgede Ižma, Kolva ja Ussa basseinis Mezenist, Võmist ja Ust-Tsilmast ümberasunutest, kes assimileerusid põlisrahvaga - euroopa metsaneenetsitega (Konakov 2000: 28-29, kaardil saab ižmalaste asuala jälgida võrguversioonis http://www.folklore.ee/ tagused/nr39/iljina.pdf). Komi esmaasukad Ižma ääres sattusid ökoloogilistesse tingimustesse, mis olid kohandatud komide traditsioonilise majapidamise funktsioneerimiseks, ja kohanesid nendega edukalt tänu uue majandusharu neenetsitelt laenatud põdrakasvatuse - juurutamisele ja täiuslikkuseni arendamisele. Põdrakasvatuskompleksi arendamise ning põhjapiirkonna taiga ja tundra hõlvamise käigus tekkis ižmalastel kultuurilis-olmeline eripära, mis väljendus rahvameditsiini ravivahendite sortimendis ja meditsiiniliste teadmiste struktuuris.

\section{Rahvafarmakopöa}

Uutes ökoloogilistes tingimustes ižmalased peaaegu loobusid taimedega ravimisest. Komi rahvaravimitena kasutatud rohkem kui 140 taimest (Iljina 1997: 36-49) on Ižma ääres fikseeritud vaid järgmiste kasutamine:

Ledum palustre L, sookail (керч) - okste kupatusvett võeti sisse köha ja hingeldustõve korral;

Betula, kask (кыдз пу) - kasekoore pealmise kihiga seoti haavu ja paiseid, kasepungade leotist joodi kõhuvalu korral;

Chamaenerium angustifolium (L.) Scop., pajulill (мупачa) - õitsva taime keeduvett võeti sisse köha korral;

Ranunculus L., tulikas (виж турун) - taimekompressi kasutati liigese-, nimme-ja luuvalu puhul;

Mentha arvensis L., põldmünt (мятнэй турун) - tõmmisega loputati angiini korral kurku, köha korral võeti seda sisse;

Plantago L., teeleht (лапкор) - värskeid lehti pandi haavale, et mäda välja tuleks ja haav kiiremini kinni kasvaks;

Achillea millefolium L., raudrohi (пороз турун) - kasutati värskeid taimi, taimetõmmise kompressi kasutati välispidiselt verdtaastava ja haavuparandava vahendina, taimetõmmist joodi liigesevalude ja -vaevuste korral; 
Oxycoccus quadripetalus Gilib., jõhvikas (турипув), Rubus chamaemorus L., rabamurakas (мырпом), Vaccinium vitis-idaea L., pohl (пув) - marju hinnati vitamiinisisalduse tõttu, muraka tupplehtede tõmmist joodi köha peletuseks.

Ižmalaste meditsiinitavasid iseloomustab kõige rohkem samblike kasutamine raviks. Cetraria islandica Ach., Islandi käokõrva (ошा сьӧд юор нитш, сбӧд нитші) kasutati kuuma kompressina valuvaigistina luu- ja liigesevalu korral, lihasevenituse raviks, käte ja jalgade tõsise väsimuse korral, pehmekshautatud samblaga hõorruti haiget külmetuse korral. Mõnikord hautati sammalt haige kuumutatud uriinis. Cladoniat, porosamblikku (еджыд нитш) kasutati skorbuudi profülaktilise vahendina või hambavalu korral.

Näitlik on järgmine võrdlus: kui rikkaliku flooraga taigapiirkonnas elavad Luza-äärsed,Višera, Ülem-Võtšegda, Ülem-Petšoora komid teadsid kõik rohkem kui 50 taime raviomadusi, siis ižmalased kasutasid igapäevaselt raviks pisut üle kümne taime, kusjuures kõige rohkem pruugiti samblikke.

Väga ilmekad on ka muutused jaanipäeva (uue kalendri kohaselt 7. juulil, vana kalendri kohaselt 24. juunil) tavades. Üldiselt arvasid komid, et suvise pööripäeva ajal on taimedes nii palju ravijõudu, et see kandub üle ka kastele. Kastet koguti aasale laotatud linastesse rättidesse, Luza ääres (komide uus rühm) veeretati end jaanipäeva öösel kasteses rohus, öeldes: Сизимдас сизим турунысь лысва - сизимдас сизим висьӧм вошас [seitsmekümne seitsme rohu kaste - seitsekümmend seitse haigust kaob] (Iljina 1977: 33). Ižma ääres arvati aga, et erilised raviomadused on just jaanipäeval maha tulnud kastel, seepärast viidi kolmel jaanijärgsel hommikul kokkuseotud rohukimp "kolme kastet koguma" [куим лысва чукӧртны], seejärel kimp kuivatati ja pandi puhtasse nurka tallele haiguse puhuks (Dukart 1978: 149; VTM 1: Terentjeva, V. F).

Ravivahendite sortiment laienes põdrakasvatustoodete laialdase ja mitmekesise kasutuse arvel. Verevaesuse, skorbuudi või neeruhaiguste vastu joodi värsket põdraverd. Arvati, et äsjatapetud looma soe veri parandab enesetunnet, tugevdab organismi ja annab uut jõudu. Põdra sulatatud luuüdi tilgutati pärast külmetust mädase põletikuga kõrva ja hägustuva sarvkestaga silma; liigestevalu ja paistetuse korral hõoruti sellega haiget kohta. Külmetuse, tugeva köha, angiini ja neeruhaiguste raviks joodi põdra jäsemete alumiste osade sulatatud luuüdi. Peaaju kasutati peapöörituse vastu. Looma maks arvati olevat hea kehvveresuse ja kollatõve puhul. Jõuetuse ja kehvveresuse korral toideti haiget põdrasarvedest keedetud kisselliga. Üsna levinud ravivahend oli põdrarasv. Külmetuse korral seda joodi, luu-ja liigesevalu ning vigastuste korral hõõruti sellega hoolikalt sisse keha. Pehmendava vahendina kasutati põd- 
rarasva ka külmetuste ja põletuste puhul. Paise küpsemise kiirendamiseks, mäda väljakiskumiseks mastiidi ja furunkuloosi korral ning skrofuloosi puhul pandi põletikulisele kohale aurutatud põdranaha kompress. Samaks otstarbeks kleebiti seebi abil paisele rasvase põdra sisenahalt nülitud õhuke kile.

Üks tervisehoidmise faktoreid on toit, sellepärast tuleb rõhutada muutusi, mis leidsid aset Ižma komide toidusedelis. Põdrakasvatajate toiduratsiooni alus on liha ja kala, mis tagavad organismile äärmuslikes klimaatilistes tingimustes vajalikud valgud ja rasvad. Igapäevased toidud olid värske, vinnutatud, kuivatatud või kergelt soolatud põdraliha, kala, linnuliha, põdralihast ja -kontidest puljongid, kalapuljongid, põdra sulatatud siserasv, puljongilt kooritud rasv, luuüdi, põdraverega pudrud ja koogid. Erilise tähendusega on toortoidud - suvel olid marjad, metsik sibul ja küüslauk mitte üksnes hooajalised maiuspalad, vaid ka vitamiinilisand, talvel rikastasid toidusedelit põdraliha- ja kalalaastud ning igal ajal maks, süda, põdraveri.

Analüüsides ižmalaste rahvaravimeid on võimatu mitte märgata neenetsi rahvameditsiini teatud mõju. Looduslikult ja majanduslikult sarnased elutingimused ja samalaadne majandustegevus võisid kaasa tuua ühesugused ravivõtted. Nähtavasti neenetsi ravivaramust võeti üle sellised vahendid nagu Islandi käokõrv, muraka tupplehed, põdra luuüdi ja seljaaju, põdrasarvekissell, sest komide rahvameditsiinile need üldiselt iseloomulikud ei ole, kuid laenates neenetsitelt põdrakasvatuskombe võisid ižmalased üle võtta ka teadmised nimetatud ainete raviomadustest. Neenetsitelt pärinevad ka mõned hügieenivõtted: näiteks laotasid põdrakasvatajad lapse hälli põdra kaelakarvu, mille alla puistati niiskust imavat kasekõdu või sammalt - sellisel alusel jäi laps alati kuivaks, sidumismaterjalina kasutati paju- või kasevitsu (Homitš 1974: 238, Vassilenko 1997: 60).

\section{Rahvatraumatoloogia ja füsioteraapia}

Üleminek põdrakasvatusele mõjutas ka meditsiiniteadmisi, aidates areneda sellisel meditsiiniharul nagu traumatoloogia. Põdrakasvataja väga traumaohtlikud olmetingimused ja kaugus asustatud punktidest rännu ajal nõudsid igalt põdrakasvatajalt oskust anda kiiret raviabi, igapäevane veterinaarkogemus tagas vajalikud anatoomilised teadmised ning aitas kaasa vastavate ravimeetodite ja -võtete tekkimisele. Sellepärast oli peaaegu igas põdrakasvataja perekonnas olemas inimene, kes suutis trauma korral abi anda. Iseloomulik on selles suhtes Gamist pärit tuntud luupaigaldaja Tandze Marja saatus (Maria Feodori t Rotševa, sünd Vitjazeva, 14. IV 1866 - 25. VIII 1962, hüüdnime pärit- 


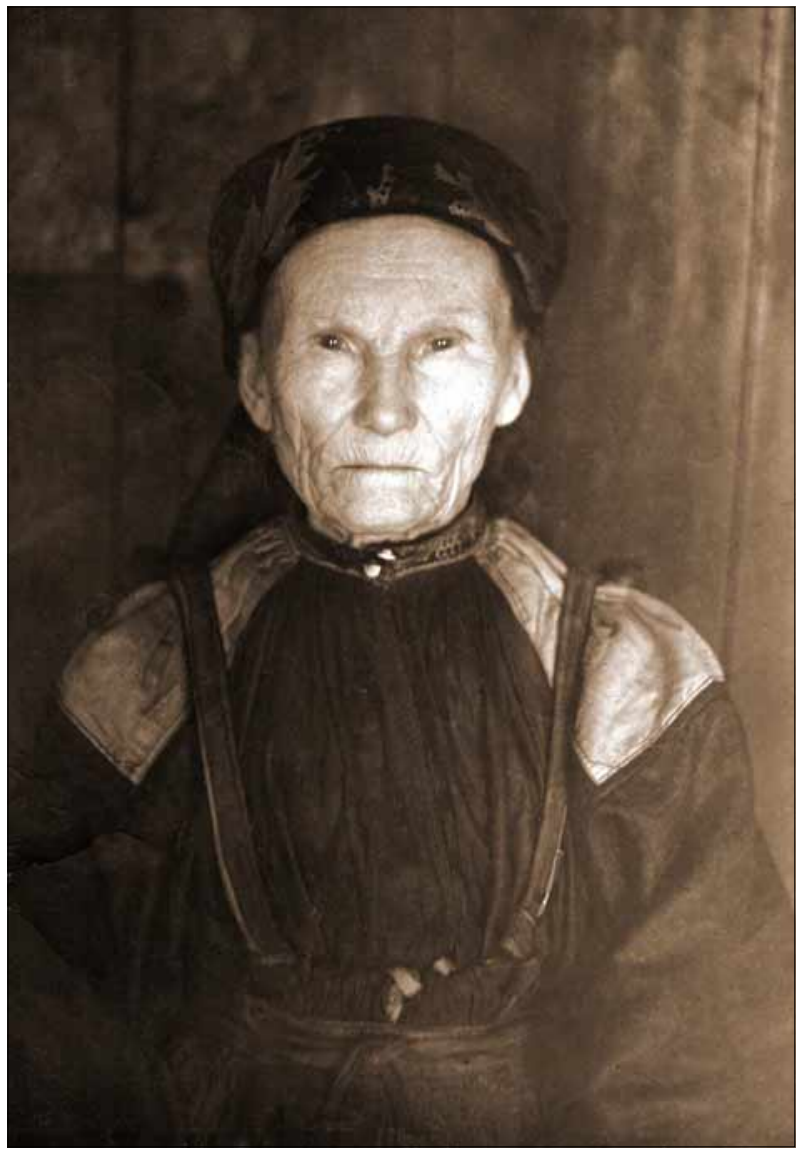

Foto 1. Tuntud Ižma luupaigaldaja Tandze Marja (Maria Feodorovna Rotševa). Foto Ižma koduloomuuseumi fondidest.

olu segane). Põdrakasvataja tundras kasvanud tütar õppis lapsest peale tundma loomade anatoomiat, seejärel hakkas isa juhendamisel osutama veterinaarabi - õppis paika seadma väljaväänatud luid, ravima venitusi ja abistama poegimise juures. 18-aastaselt hakkas ta ravitsema inimesi. Erakordse tähelepanelikkuse ja hea mäluga, tundlike käte ja tugeva iseloomuga naine saavutas meisterlikkuse ja omandas inimeste erilise tunnustuse mitte üksnes ižmalaste seas vaid kogu Petšoora keskjooksul (VTM 1: Terentjeva, Hatanzeiski, Tšuprov; VTM 2: Anufrijeva, Žilina, Semjaškina, Smetanina). Ta on näide tüüpilisest Ižma luupaigaldajast. Tänapäevani tegutsevad Ižma külades ravitsejad, kelle seas torkab silma spetsialiseerumine: on masseerijad, nikastuste paigaldajad, venituste ja rebestuste ravitsejad. 
Talutingimustes raviti vigastusi saunas. Kõigepealt haige leilitati, hõõrudes ta sisse õli või rasvaga, luupaigaldajad panid paika väljaväänatud liikmed, haiget masseeriti silitades, klopiti väljavenitatud lihaste, vigastuste ja liigesevalu korral. Keerulistel juhtumitel korrati soojendamist ja massaaži mitmel järjestikusel päeval.

Massaaž aitas, kui inimene oli ennast ära katkestanud - kõhuõõne organid olid pärast rasket tööd või koorma kandmist alla langenud. Soojendatud kõhtu masseeriti, palpeerides sügavalt alates kõhuõõne alumistest osadest kuni ribideni. Kui haigel tekkis iiveldus, katkestati protseduur silmapilk. Pärast massaaži pandi kõhule fikseeriv side, mis hoidis siseorganid ülestõstetult. Haigele soovitati kehalist rahu, kuid et seda oli põdrakasvatajal raske tagada, tuli raviprotseduuri perioodiliselt korrata.

Massaažiga püüti ravida pidevaid peavalusid ja peapööritust, mida rahvaarvamuse kohaselt kutsus esile ajunihestus pärast põrutust või järsku peapööret. Luupaigaldaja mõõtis pea ümber seotud nööriga kaugust lauba keskelt parema ja vasaku kõrvani, kõrvadest kuklakühmuni. Kui nööri üks osadest osutus teistest pikemaks, asuti ravima: luupaigaldaja masseeris pead kergete sõtkuvate, silitavate ja kloppivate liigutustega, seejärel surus seda igast suunast, justkui püüdes anda peale õiget vormi, "pani aju paika”. Kuigi haiguse põhjuse tõlgendus ja ravimisprintsiip olid naiivsed, kergendas selline massaaž sageli haige seisundit.

Luumurdude ravimiseks olid rahvaravitsejatel välja töötatud omapärased võtted. Pärast vigastatud koha põhjalikku ülevaatust seadis luupaigaldaja katkised luud paika ja pani peale vitstega toestatud kasetohust või väikestest lauakestest kerge lahase. Lahas võeti iga päev maha, murru kohta masseeriti harjaga kergelt torkivate liigutustega ( зу-nööriga seotud ja tüügaste juurest vaiguga üle valatud harjasepunt). Seejärel pandi side ja lahas jälle peale. Kui murd oli lahtine, eemaldati luutükid, haava töödeldi viina ja raudrohutõmmisega, puistati üle belemniidipulbriga ja seoti pehme riidega kinni. Lahased olid ka sel juhul ajutised ja need võeti perioodiliselt maha, luupaigaldaja kontrollis pidevalt, kas luu kasvab õigesti kokku. Luumurru pikemaks fikseerimiseks mässiti see niiskesse põdranahka, mis pärast kuivamist muutus kangeks ja hoidis jäset vajalikus asendis.

Osa ravivõtteid lähtus ettekujutusest, et haigust põhjustab "paha vere" kogunemine ja ravitseja ülesanne oli see võimalikult kiiresti ja osavalt eemaldada. Selleks kasutati rahvameditsiinis aadrilaskmist. Verelaskmise kohta kehal aurutati, avatud soone kohale paigaldati sarv, milles oli ava õhu väljaimemiseks, pärast protseduuri lõppu pandi peale tugev side. 
Ižma ravitsejad kasutasid ka järgmist ravitsemisviisi külmetuste, vigastuste, liigeste nõrkuse ja teiste vere riknemisega seotud haiguste puhul: võetakse kuiv kasekäsn, lõigatakse see lameda tassi sarnaseks, pannakse haigele kohale ja sü̈̈datakse pealtpoolt põlema. Kui sü̈̈datud käsna tuli hakkab jõudma ihuni ja haige tunneb valu - tähendab see, et selles kohas musta vere kogunemist ei ole ja käsn on vaja panna teise koha peale, kuni ihu puudutav käsn iseendast eemale põrkab. Mõnikord kargab see oma neli verssokit. See loetakse tundemärgiks, mis näitab, et sinna on kogunenud hulgaliselt paha verd. Sel juhul pannakse käsn uuesti selle koha vastu ja hoides seda millegi mittepõlevaga kõrvetatakse ihu kahe või kolme liini ${ }^{2}$ sügavuselt. Pärast seda hakkab haav mädanema ja pole sugugi haruldane, kui selle maa poole pööramisel purskab välja must, paksenenud veri ning pärast seda hakkab voolama mäda. Selles seisundis hoitakse haava seni, kuni haige saab kergendust (Kotšijev 1848: 553-554). Kuivõrd tänapäeval ükski informant enam sellist ravitsemisviisi ei kasuta, on selle efektiivsust raske hinnata, kuid analoogilised ravitsemisviisid olid tuntud ka Euroopa põhjaosa, Kaug-Ida ja Kesk-Aasia rahvaste seas (Šrenk 1855: 493; Bogojavlenski 1966: 11).

Neenetsitelt oli laenatud silmapõletiku ravimise moodus. Kevadel pärast seda kui silmad olid kogu talve olnud lume sädeluse ja püstkojas hõljuva lõkkesuitsu mõjuvallas, tekkis haigestunu meelekohas ja silmakoobastes terav valu. Neenetsid arvasid, et see on tingitud vere valgumisest silmadesse. Et sellest vabaneda, tegid nad tavaliselt noalõike ülemistesse laugudesse ja lasksid verd välja. Seejuures pandi haige selili, ravitseja keeras tal laud pahupidi ja tegi sisselõike. Seejärel pandi vastu sisselõiget lumekämbud, mis vere endasse imasid (Homitš 1974: 238).

Hoolimata ravivõtete ja -meetodite mitmekesisusest (kasutamine sõltus trauma iseloomust) ning ravitseja harjumustest ja oskustest oli luupaigaldajatel meditsiinilise abi osutamisel alati üks ühisjoon. Isegi äärmiselt rahutu haige juures vestles igaüks neist oma patsiendiga. Usalduslik, heatahtlik, kindel ja tahtejõuline toon rahustas haiget ja mõjus psühhoteraapiliselt. Seda tunnetasid ka ravitsejad, kes pidasid külmaverelisust, vastupidavust ja kannatlikkust hädavajalikeks kutseomadusteks. Ravitseja ja haige katkematu kontakt ravitsemiskäigus oli rahvameditsiinis üks efektiivsuse tagatisi.

Välitööde käigus torkab silma ižmalaste rahvameditsiini ratsionalism. Komide rahvameditsiinile iseloomulikke maagilisi ravimisvõtteid teatakse Ižma piirkonnas rahvajutu tasemel ja kasutatakse harva, peamiselt lapsi ravitsedes. Ravimaagiliste toimingute abil tohterdavad teadjad olid tavaliselt sissesõitnud. Näiteks Sizjabski külas "vana naine oli, ravis nõidusest hommikuses saunas, ta oli võtšegdalasi, aga kohalike seas selliseid ravitsejaid ei olnud" 
[пӧрысь баб вӧӧлі, лечитліс «вомыдзись» асъя пыысянын, Эжва выыса кытіськэ вӧоллі, а местнэй из вӧӧні лекарьяс] (VTM 1: Tšuprov). On iseloomulik, et termin пӧлясьысь (пӧлявны - puhuma, ära puhuma), mille etümoloogia on seotud maagiliste ravivõtetega, oli Ižmas kasutusel luupaigaldajate kohta, kelle praktikas maagilised võtted peaaegu puudusid.

Kõnekad on ka komi põdrakasvatajate suhted neenetsi šamaanidega. Uurijad on ammu täheldanud erilist austust teise rahvuse sakraalsete isikute vastu. Nii näiteks "venelased ja komid võtsid kuulda neenetsi šamaanide ettekuulutusi”, aga "neenetsid pöördusid evengi või handi šamaanide poole, pidades neid tugevamateks" (Homitš 1981: 282), Sürjani piirkond on venelaste seas kuulus nõidade poolest, "kes oskavad haigusi peale panna ja neid maha võtta" (Popov 1874: 18, Volodin 1878: 69), aga "Ust-Tsilma ja Pinega elanikke kartsid ümbritsevad rahvad, nimetades neid nõidadeks ja suure au sees olid ravitsejad-lausujad" (Venemaa Geograafilise Ühingu arhiiv: register I, nimistu 1, toimik 11, lk 12), suurte nõidadena said komi asundustes Esimese maailmasõja ajal kuulsaks mõned asumisele saadetud sõjaväekohustuslikud sakslased (Sidorov 1928: 13). Sel taustal ilmneb eriti kujukalt ižmalaste kriitiline suhtumine naabrite ravitsejatesse. Võttes neenetsitelt üle ratsionaalsed ravivahendid ja -meetodid põlastasid nad šamaanide loitsimisi haigetest kurjade vaimude väljaajamiseks, täheldades nende tulutust. "Tadibeid on petturid, ainult lollitavad inimesi, kui proovivad kedagi ravida," märgivad informandid, kes on šamaanidega ise kokku puutunud või kuulnud oma perekonna kokkupuudetest (VTM 1: Hatanzeiski, Tšuprov, Terentjeva).

Üks sellise ratsionalismi põhjusi on täiesti ilmne. Põhjapiirkondade asustamise ja uuele majandamistüübile ülemineku käigus nõudsid ohtrad traumad ja külmetused põdrakasvataja argipäevas erilist tähelepanu. Mõistuspäraste põhjustega vigastusi raviti samuti otstarbekalt. Kuid nähtavasti on siin küsimus teatud traditsiooni edasiandmises uue etnograafilise rühma moodustumise tingimustes.

Ka tänapäeval on ižmalaste, eriti vanemate ja keskealiste inimeste seas täheldatav ükskõiksus maagiliste raviriituste suhtes, mis iseloomustavad komide traditsioonilist maailmapilti. Nende seas liiguvad siiski jutud nõidadest, kes saatsid inimestele haigusi, inimesse asuvast vaimust (visjan, lišinka), kes põhjustab talle kannatusi, sauna- ja koduvaimudest, kes võivad lapse ära vahetada. 


\section{Rahvaravitseja Tandze Marja}

Vastavalt traditsioonilistele ettekujutustele moodustuvad ka jutud tuntud ravitsejatest, kelle seas on eriline koht Tandze Marjal, kellest oli eespool juttu. Rääkides isiklikust ravikogemusest rõhutatakse tema oskuslikkust manuaalteraapia vallas: "kui ta ravib, ainult sõrmed töötavad" [кор сія лечитлэма, сылэн токо чуньясыс рӧбитэны]. Rääkides oma ande edasiandmisest, on ravitseja ise öelnud: "Vaat, suren ära, ega tea, kellele oma käed edasi anda. Vaat need käed ja sõrmed oleks vaja kellelegi anda.” [Кула да меша ог тӧд, меным никодлы сетны ассюм киес. Вот этаяс, киес менум колэ сетны, чуньясэс] (Ajalooline mälu 2005: 131). Sealjuures iseloomustavad Tandze Marja isiksust jooned, mis on omased komi тӧдысь (teadja; тӧдны - teada, osata, ära arvata) mütoloogilisele kuvandile - need on sakraalsete teadmiste ja erilise andega inimesed. Pole juhuslik, et mitmes temast rääkivas tekstis on kasutatud terminit hereetik [ketser], mida kasutatakse teispoolse maailmaga ühenduses olevate posijate kohta. Ühenduses teispoolsusega muutub inimene teistest erinevaks, ja Tandze Marja "oli teistest erinev vanamemm - kõndis eriliselt, sarafane kandis omamoodi, ilusti, mitte keegi teine ei kandnud niimoodi” [ из вӧӧ весьыс кодь бабыс - ас мознаыс ветлаліс, кыдзке ас мознаыс сарафаньяс нооліс, зэй мичаа, никод сы мозыс из ноолы, ja mis kõige iseloomulikum ei vaadanud mitte kunagi silma [никор синме из визьлы] (VTM 2: Anufrijeva, Žilina).

Eriliste teadmistega varustatud posijal on anne näha salajast ja ette näha tulevikku. Kuivõrd iga ravimise käigus on ülimalt tähtis õige diagnoos, pööravad informandid tuntud posijatest rääkides sellele erilist tähelepanu. Pisut müstikasse kaldudes oletavad nad, et teadja [тӧдысь] “näeb” haigust juba enne läbivaatust. Ka Tandze Marjal oli oskus aimata läbi akna järjekordset patsienti silmates ära tema tuleku eesmärk, panna diagnoos. Õige mitmes tekstis kõlab püsitsitaat: “Tean, tean, miks tulid.” Ravimise protseduuri kirjeldatakse kiire ja märkamatuna, mis on iseloomulik imelistest paranemistest rääkivatele juttudele:

Mu äial lõi kaela: kaela painutada ei saanud, pead pöörata ei saanud. Naine viis ta Tandze Marja juurde. Ei jõudnud veel sissegi astuda, kui tema ütleb: "Tean, tean, miks tulite”. Pani äia taburetile istuma, puudutas kusagilt kaela, kusagilt silitas õrnalt, kusagilt sikutas kergelt. Aga ämm istub tema selja taga lavatsil. Nende selja taga...

"Noh, vaata taha," ütleb ta äiale, "vaata oma kaunitari."

"Kuidas ma vaatan, kui kael ei paindu?"

"Vaata, vaata, ära karda."

Pööraski mees pead: õigus, kael liigub, nagu poleks midagi olnud. 
[Батюшколы сьыыяс тшукис: сьылісэ веськедныс оз вермы, юрсэ бергӧдныс оз вермы. Бабаыс сыа нуӧдас Тандзе Марья дорэ. Пырнысныс оз успеитны, сыа висьталэ: «тӧда, тӧда, мыля воинныд». Пукседас батюшкоэс джек вылэ, эсті сьылісэ трӧнитас, эсті этша шылькнитас, эсті бара кыскыштас. А матушко сы мышку саяс пукалэ лавичын. Мышъясныс саяс... «Но, бергэччыы, висьталэ батюшколы, - визылы мада вылад». «Кыдз нэ ме бергечча, сыыыйе ке оз бергоо?» «Бергедчыы, бергедчыы, ин поо» Бергедас мужик юрсэ: и бергалэ сьыліис, бусьтэке нинэм абу и вӧӧлэма] (VTM 2: Žilina).

Motiive "diagnoos kaugelt" ja "kiire tervenemine" tugevdab mõnes tekstis motiiv "kindel paranemine", neis rõhutatakse asjaolu, et tugeva posijana võib Tandze Marja tõvest vabastada kogu eluks:

Ma sõbrustasin Tandze Marja tütretütrega. Aitasime teda palju. Ütleb: tehke seda, tooge toda. Ära öelda kartsime. Sest põhimõtteliselt ta aitas, aga mõnikord ka karistas: sellepärast kutsusid mõned teda ketseriks. Seda enam, et ta kunagi ei vaadanud inimesele otse näkku, kogu aeg vaatab kõrvale. Nii kartsimegi ära öelda. Tõsi küll, mulle ei ole ta midagi halba teinud. Vastupidi, ükskord isegi aitas. Ta nägi ise, kui inimestel ei olnud kõik korras. Vaevalt jõuad sisse astuda, tema juba teab, kus valutab. Mina olin lapsepõlves “akrobaat”: kogu aeg tegime midagi, jändasime, mürasime, ronisime igale poole. Ükskord (ma olin umbes neljateistkümnene) astusin tema poole sisse, aga tema ütleb: "Lapsuke, sinuga ei ole kõik korras. Heida õige pikali.”

Mina heitsin pikali, tema hakkas mööda kõhtu vedama. Mina jäin magama. Kaua magasin, ei mäleta. Tema äratab: "Tõuse üles, lapsuke!”

Valas mulle kange tee, andis tüki musta leiba, suhkrut. Mina sõin ja jõin selle kõik ära, ja ta ütleb mulle: "Nüüd ei valuta sul enam kunagi." Ja tõepoolest, ükskõik milliseid raskusi ma poleks hiljem tõstnud või kui raskeid töid teinud, mitte kordagi pole ära tõstnud ei naba ega selga.

[Ме Тандзе Марья нучкакед ёртаси. Зэй отсасьлім сылы. Висьталас: таес карӧ, таес вайо̆. Ӧткажитнысным полім. Сыа отавны отсаліс, но корсюрэ и накажитліс: еретничаэн мукӧдыс висьтавлісныс. Тем более, мортлы никор синме из визылы, пыр нин боке видзедэ. Эся полісныс ӧткажитныс. Мен сыэ эське нинэм лёк из карлы. Мӧдарэ на отпыр отсаліс. Сыа ачыс аддзис, кор йозыслӧн мыйке неладнэ. Тольке пыран, сыг тӧдэ нин, кытэн висе. А ме дзолядырйи «акробатка» вӧлі: пыр нин мыйке карам, нокошиччам, ыштоолам, кытчике кышасям. Корке (даснёль арэсъяс мен вӧлі) пыри сы дорэ, а сыа висьталэ: «Мыйке, нучка, тэнад 
неладнэ. Водлы ноко». Ме воді, сыа рушкуэс зырооні кучис, ме и ланьті. Дырья узи ог тӧд. Сыа сувтэдэ: «Сувт, нучка». Кисьтіс сук тшай, сьӧд нянь тор сетіс, сахар Ме весьсӧ сёйи, и менум висьталэ: «Эся никор тэнад висьны оз куччы». И забыль, мыйтта сьӧкыд иг кыпедлывлы, кычем сьӧкыд рӧбета иг рӧбитлы, никор гӧг из вӧрзьыв, кос из вӧрзыыв] (VTM 2: Anufrijeva).

Suure posija kuvand näeb ette veel ühte motiivi - vastupanu, mis komi nõiaeeposes esineb arvukates tugevate posijate omavahelisest konkurentsist pajatavates süžeedes (Sidorov 1928: 24-26). Tänapäevastes juttudes realiseerub nimetatud süžee tekstides, mis räägivad posija ja skeptiku vastasseisust, kusjuures skeptik peab mõnikord oma olemuse või sageli ametliku seisundi tõttu posija jõu proovile panema. Neis juttudes võimuesindajad kas arreteerivad või hävitavad posija või tervendab posija ametiisiku ja saavutab sellega võidu. Samalaadne tekst on Tandze Marja kohta üles kirjutatud 1984. aastal Ižma ametniku poolt, kes toona soovis jääda tundmatuks, sest tema oli luupaigaldaja poole pöördumise initsiaator.

Viiekümnendatel aastatel sõitis IŽmasse uus rajooniülemus, kes otsustas korraldada Tandze Marja üle näidiskohtuprotsessi, et karistada teda kahjuliku ebausu levitamise eest. Hakkas kohalikke inimesi küsitlema, tema kohta materjali koguma. Loomulikult soostusid vähesed tuntud luupaigaldaja vastu midagi tunnistama. Ühed olid ise temalt abi otsinud ja olid tänulikud, teised võib-olla kartsid tema võimeid. Oli, kuidas oli, aga materjali kohtuks kokku ei saadud.

Sel ajal õnnestus ülemusel jalg välja väänata. Koguni nii, et mingi ravimine, mingid haiglaid pidi käimised ei aidanud. Üks kohalik elanik, mina see olin, hakkas teda veenma, et tuleb minna Tandze Marja juurde. Alguses puikles ülemus muidugi vastu: kuidas siis nii, ise kogun tema kohta materjali ja siis lähen tema juurde!? Lõpuks näeb, et miski ei aita: jalg paistetas üles, peale astuda ei saa, ja tervenemise lootust ei mingisugust. Tuli nõustuda. Tõsi, seadis tingimuse, et mitte keegi ei saaks teada tema külastusest luupaigaldaja juurde.

Rakendatud hobusega sõitsin varahommikul ette, kella 3-4 paiku, veel pimedas jõudsime Gami. Astusime majja, memmeke istub akna all lavatsil ja ütleb: “Tean, tean, miks tulid!” Ülemusel oli ebamugav, ta saab ju aru, et Tandze Marja teab kindlasti tema pärimistest. Aga Tandze Marja pani ta lavatsile istuma, vaatas jalga ning vajutas ja mudis seda kuidagi ning siis ütleb: "Tõuse ja mine!” Too oleks peaaegu karjuma pannud: "Mõnitad või?! Ma ei saa käia, sellepärast tulingi." 
Aga tema müksab selga: "Mine-mine!” Lükkas tugevamini, ja mees astus ukse juurde, nagu poleks mitte midagi olnud.

Oma mõttest Tandze Marja kohtu alla anda ülemus loobus (VTM 1).

Komi rahvakultuuris pani pöördumine pühade teadmiste poole ja võime omandamine inimesele erilised eetilised kohustused, millest tähtsaim on keeld ravida raha eest. Selle avaldusena keelduvad ravitsejad mitte üksnes rahalisest tasust, vaid ka otsesest koostööst ükskõik millise tasulise ettevõtmisega.

Nii oli Tandze Marja elus aeg, mil, hinnates tema meetodite efektiivsust, tehti talle ettepanek töötada ametlikult haiglas. Kuid ta lükkas tagasi ettepaneku, mis oleks toonud küll väikese, aga stabiilse teenistuse: "Te katsuge ise kuidagi ravida, kui teil on selline töö, aga mina raha eest ei saa.” [ Ті кыдзке асьныд нин правитэ-лечитэ, рӧбетаныд ке сэтшем, а ме деньгаысь ог вермы] (VTM 2: Anufrijeva).

Keeld ei puuduta aga naturaaltasu kingituse, kostituse või ravimiseks tarvilike vahendite näol. Tavaliselt arvatakse, et tühjade kätega posija juurde minek tähendab tühja käiku. On jutustusi sellest, kuidas ei tohtinud ravitsejale ära öelda, kui ta midagi palus. Need tekstid viitavad ka teatud sotsioregulatiivsele funktsioonile, mida täitis posija ühiskonnas salateadmiste ja -oskuste valdamise tõttu.

Ükskord tuli Tandze Marja naabrinaise juurde, oli juba vana, elas vaeselt. "Šan'ga," ütleb, küpsetasin, aga võid ei ole. Andke natuke võid." Naabrinaisel oli võid palju, aga tal hakkas kade, ühesõnaga ei andnud ta võid, aga pärast jäi raskesti haigeks, tuli Tandze Marja poole pöörduda. "Nii," jutustas, "tuli oma ravimise eest rohkem võid viia." Aga palus ju ainult küpsetamiseks.

Veel üks juhtum. Üks naabrinaine (enam mitte see, teine) käib väga ilusa salliga. Tandze Marjale hakkas sall meeldima. Tema kohe oskas ilusat kanda. Sarafan istus tema seljas eriliselt, ka kõndis kaunilt. Palus naabrinaiselt salli, kuid naine keeldus. Nähtavasti keeldumise eest Tandze Marja karistas teda - naabrinaine jäi väga haigeks. Aga kelle juurde sa ikka lähed ravitsema? Ainult Tandze Marja juurde. Läks. Kingituse asemel võttis kaasa sellesama salli. Ja terveks sai.

Kunagi mängisid tema akna all poisikesed, tagusid palli. Ta ütles neile mitu korda: "Ärge siin akna all mängige, lööte oma palliga mul klaasid katki." Aga need ei kuulanud, mängisid edasi. Ja muidugi virutas lõppude lõpuks üks poiss palli aknasse, lõi klaasi puruks. Tandze Marja tuli välistrepile, ütles midagi justkui enda ette. Pärast läks poisil jalg paiste. Tuli tal koos vanematega minna Marja juurde. 
[Корке петас Тандзи Марья соседкаас, пӧрысь нин вӧлі, нужнэя оліс. «Шаньга, - висьталэ, - пӧжалі, а выйо̆ абу. Вый вайыштӧй. Соседкалэн вый зэй уна вӧлэма, но жалитас, оз сет выйтэ, а борас зэй ёна висьмас, лоас Тандзе Марья дорэ мунныыс. Висьтооліс: «И выйтэ коомис бурдэдчемсьыс унджык нуныым». А топ нин эд пӧжасьыштны и корлэма.

Мӧдісь вӧлэма. Соседка (абу сыа, мӧд нин) зэй мича шалля ветлалэ. Тандзи Марьялы шаль зэй гляниччас. А сыа кужис мичасэ ноолыныс, сарафаныс сы вылын кыдзке ас мознаыс пукаліс, да и ветлаліс зэй мичаа. Корас шальсэ соседкалысь, но женщинаыд оз сет. Тодд нин, Тандзе Марья накажитіс - соседка висьмас ёна. А код дорэ мунан бурдэдчыныд? Тольке Тандзе Марья дынэ. Мунас. Козин пыдылясь нуас шальтэ. И правитчас.

Корке ӧшинь уутас детинаяс ворсэныс, мяч чужъялэныс. Сыа кымыніське висьтоолас налы: «Ин эстэн ӧшинь уутас ворсэ, менсюм стеклэ пазэданныд» А ныа оз кыызыныс, водзе ворсэныс. И тӧд нин, ӧти детинка мячад чужъяс и ӧшиньтэ пазэдас. Тандзи Марья петас кыльчи вылас да вомулас мыйке висьталас. И детиналэн эся кок пыкталас. Лоас ай-мамыскэд Тандзе Марья дорэ муннысныс] (VTM 2: Anufrijeva).

Iseloomulik on asjaolu, et informandid ei tauni mingilgi määral Tandze Marjat, isegi mitte neil juhtumitel, kui karistus järgneb tema omakasupüüdliku palve mittetäitmisele. Kirjeldatud juhtumeid käsitletakse kui külanaabrite karistamist ihnsuse, ahnuse ja kuulmatuse eest.

Vastavalt ande pärimise reeglitele läheb eriline ravivõime edasi Ižma luupaigaldaja järeltulijatele. Praegu praktiseerivad tema õe- ja vennalapselapsed, kuigi vaevalt on nad läbi teinud pika tavakohase väljaõppe.

\section{Ravitsejakultuse teke}

Tandze Marja mütologiseerimine viis omalaadse ravitsejakultuseni, mis on kinnistunud Ižma-äärsetes külades ja millel ei ole komide teistes rühmades analoogi. Alus sellele pandi luupaigaldaja eluajal, mil tema praksis saavutas üleüldise tunnustuse, ja arenes edasi komidel hästi säilinud esivanemate kultuse raames. Külanaabrite jutu järgi tuli Tandze Marja matustele nii palju tänulikke inimesi, et matuserong venis kolme kilomeetri pikkuseks. Järgmistel aastakümnetel püsisid mälestused kohaliku luupaigaldaja ainulaadsetest võimetest. Sajandivahetuse künnisel muutus austusobjektiks tema haud Gami 


\section{Irina Iljina}

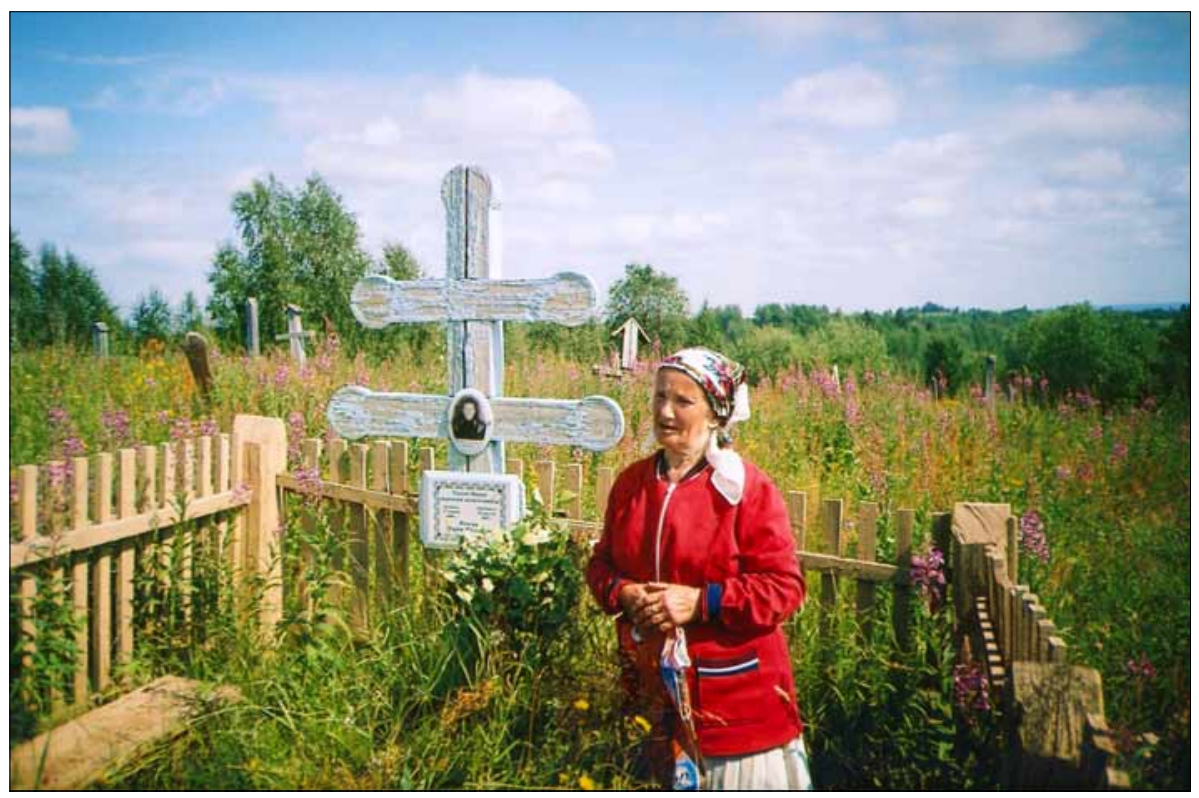

Foto 2. Ižma-äärsetes külades on tekkinud omalaadne Tandze Marja kultus. Tema haud on saanud austusobjektiks ja torkab külakalmistul silma erilise kujundusega. Autori foto.

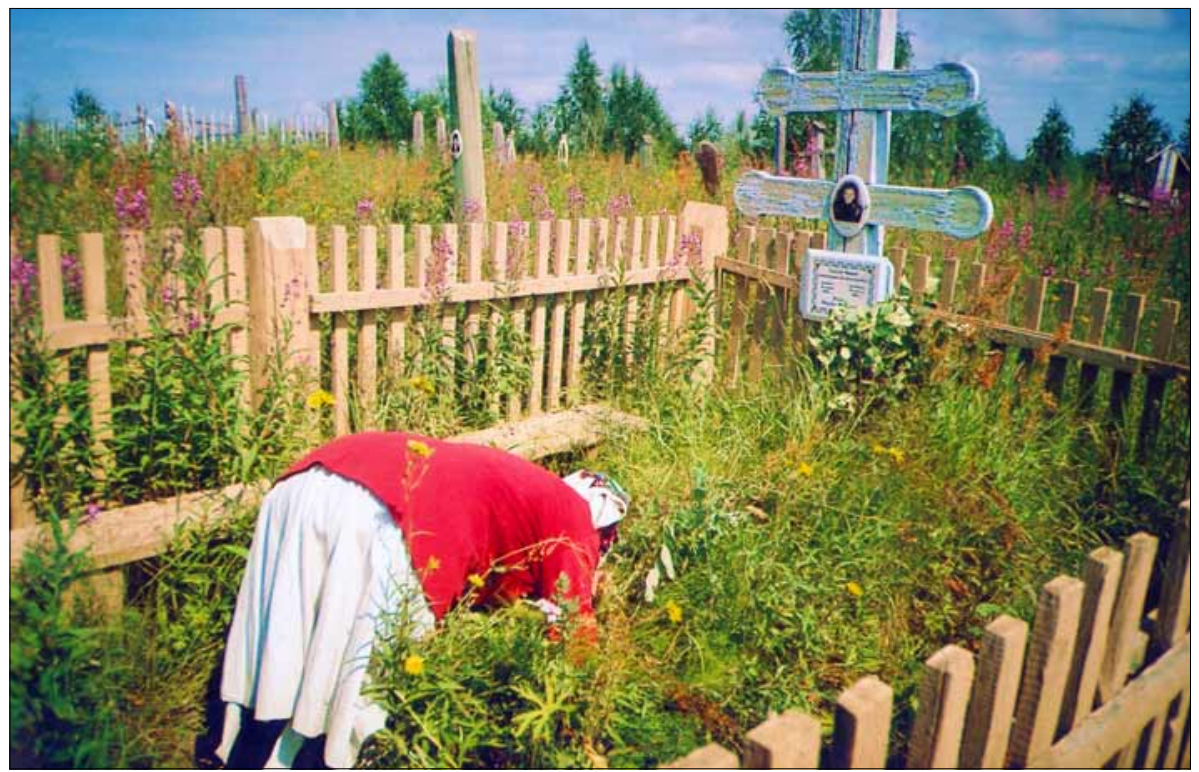

Foto 3. Tandze Marja hauale minnakse haiguse või õnnetuse korral. Arvatakse, et tervenemiseks tuleb heita kalmule ja paluda vanaema Marjalt abi. Autori foto. 
küla vanal kalmistul. Informantide sõnul tuleb haiguse korral "minna hauale, heita sellele ja paluda vanaemalt” tervendust [колэ мцгила вылас воныс, водныс сы вылэ и корныс бабыслысь]. Naised usuvad, et hauakääpa muld aitab Mariadel end ravida ja õnnetusest eemal hoida - selleks tuleb võtta kääpalt näpuotsatäis mulda ja seda endaga kaasas kanda (VTM 2: Anufrijeva, Žilina). Kokkuvõttes sobivad sellised rituaalid hästi traditsiooniliste ettekujutustega, mille kohaselt viibivad surnud esivanemad (важ циоз - vanad inimesed, рӧдительяс - vanemad) nähtamatult oma järglaste kõrval ja aitavad neid raskes olukorras, samuti sobib see ettekujutusega haige nimekaimu erilisest osast maagilises ravitsemisriituses (Uljašov 2000: 149; Panjukov 2003: 10-11).

Komid nimetavad tavaliselt kaitsjateks eellasi neljanda põlveni või tädisid ja onusid, kelle soosingus oli inimene eluajal (Uljašov 2000: 149), ja pole teada ühe isiku austamist üleüldise kaitsjana, väljaarvatud religioossed juhtumid. Peale selle on tähelepanuväärne, et kõige nõutumaks muutus ravitseja kuvand viimasel aastakümnendil, kui kohalik intelligents algatas Tandze Marja kalmu korrastamise ja temast rääkivad publikatsioonid ajakirjanduses (nt Anufrijeva 2003: 6-7; Smetanina 2006: 5). Raamatukogus, Gami küla kultuurielu keskuses, on kohaliku piirkonna uurimise entusiast T. Z. Smetanina loonud ravitsejaga seotud materjalidest nurgakese, taastatakse Vitjazevite sugupuud, kusjuures välja on selgitatud sugulased, kes siirdusid Uuralite taha 19. sajandil, korraldatakse Tandze Marja mälestusõhtuid, kuhu kutsutakse lähikülades elavaid järglasi. On iseloomulik, et näitusel esitatud materjalid jätavad mõneti idealistliku pildi ravitsejast, kes "kõiki aitas, kõiki ravis, isegi Moskvast ja Leningradist, kõikjalt” (Ajalooline mälu 2005: 131). Samal ajal puuduvad eeltooduile sarnased tekstid, mis kajastavad ravitseja poolt saadetud karistusi, kuigi rahvasuus on nad laialt liikvel ja kahtlemata teavad neid ka koduuurijad. Tekib mulje, et Tandze Marjat austavate kohalike inimeste silmis diskrediteerivad need tekstid ravitsejat, ja nad valivad materjali ühekülgselt, lähtudes võib-olla oma subjektiivsest ettekujutusest, milline peab olema ideaalne rahvaravitseja. Ettekujutuse vormumisele võivad olla kaasa aidanud tänapäevased massiteabevahendid.

See kõik lubab näha Ižma ravitseja erilises austuses Ižma komide teatud etnopoliitilist püüdlust põhjendada oma staatust eraldi rahvusena. Võttes arvesse asjaolu, et etnilist ühtsust toetavaks peamiseks identifitseerivaks elemendiks on uhkus oma rahva mineviku üle, tuleb tunnistada, et ainulaadse ravitseja isiksus sobib rahvuskangelase, väärika eellase rolli paremini kui ükski teine. Kohalikul intelligentsil on lisastiimul vormistada ametlikult rahvatraditsiooni raames kujunenud Tandze Marja kultus, keda austavad ja kellele on tänulikud kõik Ižma komide põlvkonnad. 
Kokkuvõtteks on oluline märkida, et vaatamata riikliku tervishoiusüsteemi määravale osale on viimasel aastakümnel mitmel põhjusel sotsiaalmajanduslikus, meditsiinilises ja eetilises plaanis järsult suurenenud huvi rahvalike ravimooduste ja rahvaravitsejate tegevuse vastu mitte üksnes elanikkonna, vaid ka meedikute ja bioloogide seas. Ižma-sarnased lokaalsed traditsioonid annavad konkreetsete ökoloogiliste tingimustega kohanemise ainulaadse kogemuse ning avavad teadusliku ja rahvameditsiini koostoime tulevikuväljavaate.

\section{Kommentaarid}

1 Artikkel on valminud Venemaa Teaduste Akadeemia presiidiumi fundamentaaluuringute programmi "Rahvaste ja kultuuride kohanemine looduskeskkonna sotsiaalsete ja tehnoloogiliste transformatsioonidega".

2 Üldiselt on liin mõõtühik, millele vastab 1/10 tolli (2,54 mm). Võimalik, et liiniks või jooneks loeti vanasti põletuseks kasutatava kasekäsnast tassi paksust.

\section{Kirjandus}

Ajalooline mälu 2005 = Историческая память в устных преданиях коми: материалы. Анкундинова, Марина А. \& Филиппова, Валентина В. (koost). Сыктывкар, 2005.

Anufrijeva 2003 = Ануфриева, Александра С. Тандзе Марья. Би кинь 11.

Bogojavlenski 1966 = Богоявленский, Николай А. Медицина у первоселов русского Севера. Ленинград, 1966.

Dukart 1978 = Дукарт, Нина И. Весенне-летние праздники и обряды в северной деревне концаXIX - начала XX в. Вопросы истории Коми АССР (Труды Института языка, литературы и истории Коми филиала АН СССР 16). Сыктывкар, lk 141-152.

Homitš 1974 = Хомич, Людмила В. Материалы по народным знаниям ненцев. Гурвич, И. С. (toim). Социальная организация и культура народов Севера. Москва, lk 231-248.

Homitš 1981 = Хомич, Людмила В. Шаманы у ненцев. Проблемы общественного сознания аборигенов Сибири. Ленинград: Наука.

Iljina 1997 = Ильина, Ирина. Народная медицина коми. Сыктывкар.

Konakov 2000 = Конаков, Николай Д. Этнографические группы коми-зырян. Мокшин, Николай Ф. \& Федянович, Тамара П. \& Христолюбова, Людмила С. (toim). Народы Поволжья и Приуралья. Москва, lk 26-30.

Kotšijev 1848 = Кочиев. Зырянские обычаи. Вологодские губернские ведомости 49.

Panjukov 2003 = Панюков, Анатолий В. Этнолингвистический аспект изучения заговорной традиции коми: ним кыв видзем. Сыктывкар, 2003. 
Popov $1874=$ =опов, Клавдий. Зыряне и зырянский край. Нзвестия Нмператорского общества любителей естествознания, археологии и этнографии при Московском университете XIII. 2. väljaanne. Москва.

Sidorov 1928 = Сидоров, Алексей С. Знахарство, колдовство и порча у народа коми. Ленинград, 1928.

Smetanina 2006 = Сметанина, Тамара 3. Гамса лекар. Новый Север. 5 июля 2006.

Uljašov 2000 = Уляшев, Олег И. Культ предков. Мокшин, Николай Ф. \& Федянович, Тамара П. \& Христолюбова, Людмила С. (toim). Народы Поволжья и Приуралья. Москва, lk 144-150.

Šrenk 1855 = Шренк, Александр. Путешествие к северо-востоку Европейской России. Санкт-Петербург, 1855.

Vassilenko 1997 = Василенко, Борис И. Народная медицина ненцев Ямала. Салехард, 1997.

Volodin \& Iljina $2000=$ Володин, Владимир В. \& Ильина, Ирина В. Народная медицина коми в системе этнокультурной адаптации. Коренные этносы Севера европейской части России на пороге нового тысячелетия: история, современность, перспективы. Материалы международной научной конференции (Сыктывкар, 1719 мая 2000 г). Сыктывкар.

Vologdin 1878 = Вологдин, Петр В. Лесное царство. Слово. Санкт-Петербург, 1878.

VTM (autori välitööde materjalid) $1=$ Полевые материалы экспедиции автора в Ижемский р-н Республики Коми, июль 1984 г. (информаторы Терентьева, Валентина Ф. \& Хатанзейский, Николай К. \& Чупров, Тимофей С.).

VTM (autori välitööde materjalid) $2=$ Полевые материалы экспедиции автора в Ижемский р-н Республики Коми, август 2006 г. (информаторы Ануфриева, Роза Г. \& Жилина, Татьяна И. \& Семяшкина, Мария Д. \& Сметанина, Тамара 3.).

\section{Summary}

\section{Regional Nordic Tradition in the Komi Folk Medicine}

Irina Ilyina

Key words: cultural adaptation, folk healers, folk medicine, indigenous peoples of Northern Europe, Komi

The article based on field work materials discusses the characteristics of folk medicine among the northernmost group of the Komi - namely, those living in the Izhemsky District (Komi $i z^{\prime} v a$ ). During the populating of the tundra and the development of reindeer herding tradition borrowed from the Nenets, the Izhma Komi developed a striking cultural and practical character which is expressed in the structure of medical 
knowledge, the range of remedies and treatment methods, and the system of nutrition and hygienic tradition. The folk medicine of the said ethnic group is characterised by remarkable rationality, which is expressed in a rare use of magical treatment methods, the majority of folk healers are bone-setters, and a sceptical attitude towards the Nenets Shamans is prevailing.

In the framework of ancestral worship practised by the Komi developed the cult of Tandze Marya, a famous folk healer and bone-setter. The mythologisation of the wellknown healer has been greatly facilitated by the means of mass media, which has, in some respects, appeared on the initiative of local intellectuals. 